\title{
PEDAGOGIA CRÍTICA E RESISTÊNCIA: contributos do pensamento de Paulo Freire em tempos de colapsos da democracia - entrevista com Peter McLaren 1
}

\author{
Maria Vieira Silva \\ Universidade Federal de Uberlândia - UFU, Brasil
}

\begin{abstract}
Resumo
Paulo Freire completa, em 2021 um século de existência. As divisões do tempo em ciclos temporais são constructos culturais e simbologias sociais, assim, aos nos referenciarmos neste recorte temporal, não pretendemos substancializar o tempo histórico de forma reificada, mas, a partir de um movimento dialético entre passado e presente, buscamos, por meio das memórias e narrativas ensejar reflexões e diálogos indagativos sobre o legado de Paulo Freire para a educação transformadora. Esta entrevista proporcionará tessituras de memórias acerca da relevância da obra de Paulo Freire em favor dos oprimidos, dos "esfarrapados do mundo", daqueles que tiveram sua voz silenciada e sua vez subjugada, por meio do olhar de um grande intelectual: Peter McLaren. Ao longo de décadas, McLaren tem construído importantes contributos para a solidificação da teoria crítica fomentando políticas e práticas educacionais contra as várias formas de opressão e teorizações que ajudam edificar modos de educação necessários para as lutas contra-hegemônicas e enfrentamento às atuais dinâmicas de poder das políticas neoliberais e neoconservadoras. Suas formulações teóricas apresentam nexos importantes com o pensamento de Paulo Freire, e, por meio de várias obras, tem contribuído para disseminar a teoria freireana em diferentes países, fazendo circular, de forma potente, utopias de justiça social e defesa da dignidade de grupos excluídos e oprimidos.
\end{abstract}

Palavras-chave: Pedagogia crítica; Epistemologias de Paulo Freire; Poder e libertação.

\begin{abstract}
Paulo Freire completes, in 2021, a century of existence. The divisions of time in time cycles are cultural constructs and social symbologies, so, when referring to this time frame, we do not intend to substantiate historical time in a reified way, but from a dialectical movement between past and present, we seek through memories and narratives, to give rise to reflections and inquiring dialogues about Paulo Freire's legacy for transformative education. Through the eyes of the great intellectual Peter McLaren, this interview will provide tessitura of memories about the relevance of Paulo Freire's work in favor of the oppressed, of the "ragged of the world," of those who had their voice silenced and their turn subdued. For decades, McLaren has made important contributions to solidification of critical theory fostering educational policies and practices against various forms of oppression. By reframing the concept of culture and intellectuals, it produces theorizations that help to build the necessary education modes for counter-hegemonic struggles and confronting the current power dynamics of neoliberal and neoconservative policies. Its theoretical formulations have important nexuses with the thought of Paulo Freire, and, through various works, Giroux has contributed to spread Freire's theory in different countries, circulating utopias of social justice and defending the dignity of excluded and oppressed groups in a potent way.
\end{abstract}

Keywords: Critical Pedagogy; Epistemology of Paulo Freire; Power and Liberation.

ISSN 1645-1384 (online) www.curriculosemfronteiras.org 
Compositor de destinos

Tambor de todos os ritmos

Тетро, tетро, tempo, tempo

Caetano Veloso

\begin{tabular}{|l|l|}
\hline & $\begin{array}{l}\text { Peter McLaren é professor emérito em Estudos } \\
\text { Críticos da Faculdade de Estudos } \\
\text { Educacionais da Universidade Chapman; } \\
\text { professor emérito da Universidade da } \\
\text { Califórnia (Los Angeles - EUA) e professor } \\
\text { titular da Northeast Normal University, China. } \\
\text { É autor e editor de mais de 50 livros, seus } \\
\text { escritos foram traduzidos para vinte idiomas, } \\
\text { tendo recebido várias premiações por suas } \\
\text { obras como também prêmios vitalícios por seu } \\
\text { ativismo político. Autor de conceitos originais } \\
\text { tais como Pedagogia Crítica e } \\
\text { Multiculturalismo Revolucionário - dentre } \\
\text { outros - as teorizações de McLaren produzem } \\
\text { nexos entre a pesquisa educacional e a prática } \\
\text { pedagógica nas escolas, fomentam a } \\
\text { atualidade da Pedagogia da Libertação e } \\
\text { contribuem para uma pedagogia capaz de } \\
\text { reconhecer as transmutações cotidianas do } \\
\text { capital e de organizar a resistência diária. }\end{array}$ \\
Foto: acervo Maria Vieira Silva - Chapman University \\
(Califórnia - EUA) em 03/07/2018
\end{tabular}

Há mais de meio século ${ }^{2}$, as obras de Paulo Freire têm proporcionado efetivos contributos para a solidificação da Pedagogia Crítica em vários países. Em muitas passagens, observamos fortes vínculos entre a base de pensamento freireano e suas concepções de sociedade, sujeito e educação, assim como as bandeiras defendidas em várias ações de seu ativismo político. Face a esta constatação, gostaríamos que recuperasse memórias de sua aproximação com Paulo Freire e algumas marcas que definiram a sintonia entre as teorizações de vocês.

Peter McLaren: Obrigado por sua questão. É uma honra refletir com vocês sobre o legado de meu amigo e mentor Paulo Freire. Tenho pensado no ano em que foi publicada a primeira edição em português do livro "Pedagogia do Oprimido", que foi, creio eu, em 1968 (a versão em inglês saiu em 1970). O que estava acontecendo ao redor do mundo naquele momento?

Bem, o que algumas pessoas denominam de "A Revolução de 1968" - uma configuração política de vozes minoritárias levadas para as ruas com o objetivo de serem ouvidas - estava acontecendo em muitos países em todo o mundo. Esses grupos estavam se posicionando contra os "quatro cavaleiros da opressão" - capitalismo, racismo, misoginia e ganância - todos usando o manto estrelado do imperialismo dos EUA e da supremacia branca 
(anglo-americana). O ano de 1968 pode ser representado nos anais da esquerda como uma girândola lançando mil foguetes no céu, em um heróico grito de liberdade. Naquele momento, um levante de estudantes e trabalhadores no Paquistão derrubou um ditador apoiado pelos EUA. Os motoristas de scooters de riquixá juntaram-se aos membros da classe média e marcharam juntos nas ruas. O ano de 1968 não foi apenas uma rebelião da juventude movida a flores, mas, percebendo que o sonho americano realmente significava viver ao lado do boulevard dos sonhos desfeitos - foi principalmente um punho erguido em apoio aos trabalhadores em todo o mundo lutando pela autogestão dos trabalhadores e pela democracia direta.

Foi o ano da Ofensiva do Tet no Vietnã , quando os norte-vietnamitas foram capazes de fazer alguns ganhos militares estratégicos contra o que era considerada a máquina militar invencível dos Estados Unidos, o que chocou o mundo. Grande parte da oposição à guerra do Vietnã foi inspirada pelo grande Martin Luther King e sua luta pelos direitos civis no início dos anos 1960. E quem poderia esquecer o movimento pela liberdade de expressão em Berkeley ou o movimento da Nova Esquerda, ou os movimentos de mulheres e gays e lésbicas que se seguiram? Os Panteras Negras, os Jovens Lordes, Malcolm X, estavam mobilizando comunidades negras. Pessoas em todo os Estados Unidos testemunharam a polícia espancando violentamente os manifestantes na Convenção Nacional Democrata de 1968 no Anfiteatro Internacional em Chicago.

A grande revolta dos trabalhadores de 1968 envolveu milhões de manifestantes e tomou a forma de uma greve geral e onda de ocupações de fábricas na França. Isso foi um ano após o assassinato de Che Guevara. Os ecos da Comuna de Paris de 1871 reverberavam das ruas de Paris para ao redor do mundo. Muita indignação foi dirigida contra a guerra da França contra a luta da Argélia pela libertação nacional. Foi quando comecei a conhecer a obra de Frantz Fanon. Quem pode esquecer a luta dos estudantes contra as ações violentas de policiais com cassetetes na Sorbonne? Quem pode esquecer as batalhas entre os estudantes e a polícia nas ruas de paralelepípedos de Paris? Quem pode esquecer a Noite das Barricadas? Quem pode esquecer a notícia de que dez milhões de trabalhadores entraram em greve? Todos nós lembramos do horror do massacre de Tlatelolco (2 de outubro de 1968) na Cidade do México, no qual centenas de estudantes foram assassinados pelos militares para garantir que não haveria protestos políticos durante os Jogos Olímpicos. Houve protestos em todo o mundo envolvendo ambientalistas, grupos indígenas, hippies, feministas e trabalhadores migrantes. Foi um ano de manifestos, drogas e rock. O maoísmo estava em ascensão e o Pacto de Varsóvia invadiu a Tchecoslováquia.

Foi nesse ano que deixei o porto seguro da casa de minha família em Toronto e entrei em um ônibus - e depois peguei carona - para ir a Los Angeles e São Francisco para participar dos protestos contra a guerra do Vietnã. Inquestionavelmente, a inspiração política que desencadeou os acontecimentos de 1968 penetrou no pensamento de Freire, levando à publicação da Pedagogia do Oprimido em 1968. É claro que Freire fora preso após o golpe de Estado de 1964 [no Brasil] uma vez que o novo regime instaurado considerava que seu trabalho continha elementos subversivos, como os "Círculos de Cultura" os quais o governo 
[João Goulart] planejava expandir durante o período 1963-64. E em 1967 Freire publicou seu primeiro livro, "Educação como prática da liberdade".

Mas foi emblemático da época que Pedagogia do Oprimido - que viria a se tornar sua obra seminal - foi publicado pela primeira vez em 1968. No entanto, eu não tive acesso ao trabalho de Paulo até mais de uma década depois. Não havia qualquer menção ao seu trabalho em Toronto Teacher's College, onde realizei meus estudos e me habilitei para me tornar um professor do ensino fundamental e médio. Conheci o trabalho de Paulo enquanto desenvolvia estudos para meu doutorado, no Departamento de Currículo e Instrução do Instituto de Estudos em Educação de Ontário, mas, seu trabalho não constava no currículo oficial, pelo menos até 1984, quando me formei. Talvez estivesse sendo ensinado em outros departamentos, não sei, mas tive a impressão de que eles estavam escondendo o trabalho de Paulo dos alunos naquela época. Conheci o trabalho de Paulo indiretamente ao ler sobre o "Teatro e Experimentação Radical" de Augusto Boal, que me foi recomendado pelo orientador de minha tese, Richard Courtney, mundialmente famoso como especialista em drama infantil. Mas, as perspectivas socialistas, anti-racistas e antiimperialistas que faziam parte do discurso da Nova Esquerda à época, penetraram primeiramente em meu pensamento durante aulas com professores visitantes como Michel Foucault, Ernesto Laclau, Umberto Eco e outros.

Só conheci Paulo pessoalmente em 1985, tendo sido apresentado a ele por Donaldo Macedo e Henry Giroux. Paulo foi muito generoso em elaborar dois prefácios para livros que eu estava escrevendo à época. No Prefácio do meu livro, Predatory Culture, ele se referiu a mim como seu "primo intelectual", o que foi emblemático de sua gentileza em mostrar tamanha generosidade de espírito a um neófito no mundo acadêmico que tentava encontrar seu caminho no tumultuado - e muitas vezes competitivo - espaço da vida universitária em meu país recém-adotado, os Estados Unidos. Fiquei surpreso por ele ter lido meu trabalho. Eu tinha acabado de me mudar para os Estados Unidos, vindo do Canadá, para trabalhar com Henry Giroux, e meu encontro com Paulo aconteceu em uma conferência educacional em Chicago - uma das maiores conferências desse tipo no mundo. Paulo rapidamente encheu um grande auditório com participantes entusiasmados. Paulo era o remédio de que o país precisava. E ainda precisa, agora mais do que nunca!

Em 1987 fui convidado por Paulo para um congresso de psicologia em Havana, Cuba, e sabia que Paulo era um admirador de Che e Fidel, e eu nunca tinha estado em Cuba. Mas, não pude ver Paulo em Havana porque soube que ele havia saído da conferência e estava se reunindo com educadores populares e representantes do Ministério da Educação, na "Casa de las Américas". O mais importante nessa conferência foi a oportunidade de me encontrar com educadores brasileiros e mexicanos que tiveram a gentileza de me convidar para suas instituições e de me levar pelas favelas, para visitar grupos de educação popular e me apresentar a histórica experiência brasileira de educação popular. Foi nessa época que me interessei pela Umbanda, Candomblé e pelo Espiritismo. 


\section{Como expressivo estudioso e grande interlocutor dos princípios freireanos, quais as chaves analíticas centrais para compreender a base do pensamento de Freire e inspirar novas possibilidades de "ler o mundo"?}

Peter McLaren: No livro Pedagogia do Oprimido, Paulo se refere ao diário de Che Guevara, no que diz respeito à ênfase de Che ao poder da ideologia - como o opressor pode se hospedar nas mentes dos oprimidos. Freire descreve isso como a "internalização do opressor pela consciência dominada dos camponeses". Nesse sentido, Freire me inspirou a desconstruir as formas pelas quais minha formação pessoal e profissional como professor foi cúmplice nas relações de dominação e subordinação, e me inspirou a fazer uma leitura séria de obras sobre ideologia, consciência, colonialismo, neocolonialismo, a partir de uma variedade de perspectivas disciplinares - antropológica, psicológica, fenomenológica, existencial, teológica, marxista. Ele também me ajudou a abordar minha fé católica. Ele era profundamente cristão, mas também muito crítico do clericalismo da Igreja. Recentemente, publiquei um livro criticando doutrinas de evangélicos que apoiam Trump, e como eles deturparam os ensinamentos de Jesus. Fiquei interessado na Teologia da Libertação durante visitas ao Brasil, México, Argentina, Colômbia e Venezuela, e fiquei muito satisfeito quando o teólogo brasileiro Leonardo Boff concordou em escrever um prefácio para a quarta edição do meu livro, Life in Schools.

Em 1987, eu estava debatendo as várias ideias do pós-modernismo na educação e essas ideias costumavam ser acompanhadas por vários ataques, em razão de estarem alinhadas com as bases do pensamento marxista. Eu percebi que muitos desses ataques à teoria marxista eram caricaturas da obra de Marx. Foi só em 1995 que comecei a escrever como marxista e freiriano, é claro! Percebi que muitos professores e educadores freirianos nos Estados Unidos estavam escrevendo a partir de uma postura progressista que parecia sugerir que o capitalismo poderia ser ajustado para atender às necessidades das classes pobres e excluídas. Eu discordei. Era minha crença, e ainda é, que precisamos criar uma alternativa socialista ao capitalismo - um universo social fora da formação de valor do capital. Portanto, em vez de usar o termo "pedagogia crítica", tomei a decisão de me referir ao meu trabalho como "pedagogia crítica revolucionária", a fim de enfatizar a importância de lutar por uma alternativa socialista ao capitalismo. Essencialmente, significava adotar uma abordagem marxista humanista da pedagogia crítica, e mais tarde tentei integrá-la à Teologia da Libertação.

Não tive oportunidade de discutir isso com Paulo, mas acredito que ele teria aprovado uma trajetória socialista - afinal, ele foi influenciado por pensadores como o filósofo tcheco Karel Kosik e o filósofo da educação polonês e marxista Bogdan Suchodolski. A obra Ação Cultural pela Liberdade (1970), e a luta por uma sociedade democrática socialista que ilumina a Pedagogia da Esperança (1994) são dois textos onde o socialismo mais estimula a busca de Freire pelo socialismo como um caminho de libertação, como um caminho para a liberdade. Se pudesse criar uma nova palavra a partir da leitura da obra Pedagogia da Esperança de Freire, talvez possamos chamar Freire de "Socialista Esperançoso". 
Fui visitar Paulo em sua casa em São Paulo, e ele até se ofereceu para ajudar a traduzir uma palestra minha em São Paulo. Quando Paulo visitou os Estados Unidos, tive a oportunidade de encontrá-lo em algumas ocasiões, e uma conferência memorável aconteceu em Boston quando vários educadores, incluindo eu, bell hooks, Antonia Darder, Henry Giroux, Donaldo Macedo e outros, tiveram a oportunidade de fazer perguntas a Paulo sobre seu trabalho e como ele estava sendo interpretado nos Estados Unidos. O evento mais memorável para mim foi no Rose Theatre em Omaha, Nebraska - acho que foi em 1996 durante uma Conferência de Pedagogia do Oprimido, quando Paulo, Augusto Boal e eu participamos de um painel de discussão juntos. Essa foi a primeira aparição pública de Paulo e Augusto juntos, aparentemente. Eu me senti afortunado por estar com eles. Paulo Freire, a meu ver, é o pensador educacional mais importante do século XX e não há razão para acreditar que ele também não se tornará o pensador mais importante do século XXI. Visitei cerca de trinta países nos meus 30 anos como educador e, em todas essas visitas, o trabalho de Paulo Freire serviu como a liga epistêmica e ética comum que tive com meus anfitriões e com os educadores com quem tive a oportunidade de conhecer que estavam lutando por justiça social.

Hoje o trabalho de Freire tornou-se mais importante do que nunca. Nos Estados Unidos, saturado de teorias de conspiração, estamos desesperançados frente a fraude da falta de razão. A turbulência de navegar pelos escombros da política pós-verdade durante uma pandemia de proporções incomparáveis (a menos queiramos considerar a Gripe Espanhola de 1918), ocorreu em meio a protestos heróicos dos direitos civis sob a bandeira de Black Lives Matter em resposta ao assassinato de George Floyd e a brutalidade infligida pela polícia aos afroamericanos e o desastre planetário iminente devido à mudança climática, persuadiu muitos americanos a se renderem a uma política autoritária caracterizada pelo etno-nacionalismo branco e a escolherem uma supremacia branca, em vez de promover relações recíprocas de respeito, compreensão e solidariedade com pessoas de cor. Isso fez da expansão da pedagogia crítica revolucionária e da obra de Paulo Freire uma proposta urgente.

As históricas assimetrias sociais assim como a ascensão de agendas governamentais conservadoras no tempo presente e o decorrente colapso de políticas sociais têm agudizado processos de exclusão social de estratos empobrecidos. Que aspectos da obra de Paulo Freire poderia destacar como legados fundamentais na incessante luta contra as várias formas de opressão de grupos marginalizados?

Que ideias de Freire se destacam para mim? Para mim, a ideia de Freire de que somos seres humanos inacabados desempenha uma parte importante do meu pensamento educacional até hoje, assim como a ideia de Freire de viabilidade não testada. Sua ideia de que não devemos importar suas ideias para os Estados Unidos, mas sim recriar e reinventar suas ideias, é outra. Sua ideia de que ler não é memorizar ideias, mas reescrevê-las, é outra. Suas ideias sobre a teoria dialógica e libertadora, sobre a leitura da palavra e do mundo, sobre a práxis ontológica - essas se tornaram ideias básicas para todos nós interessados em justiça 
social e práxis libertadora - e muitas dessas ideias foram bastante iluminadas por Nita Freire. Freire usa o termo "situação limite" para se referir a problemas espinhosos que são difíceis de superar porque somos limitados por situações concretas em nossas vidas.

Situações de limite tornam-se barreiras e obstáculos para alcançar nossos objetivos, mas, muitas vezes, podem ser superadas pela descoberta de uma viabilidade não testada por meio do diálogo coletivo recíproco - superando assim uma situação considerada impossível ou impraticável simplesmente porque não era previsível. $\mathrm{O}$ fato de os oprimidos perceberem que seus opressores veem o poder dos oprimidos como um limite ao seu próprio poder e privilégio é uma percepção que deu muita força e compreensão aos grupos oprimidos. Um insight assimilado por meus grupos de alunos mais privilegiados é a compreensão de que relações assimétricas de poder e privilégio nunca são politicamente neutras. $\mathrm{O}$ trabalho de Freire na decodificação de temas - codificações - ajudou muitos professores norte-americanos a trabalhar com os alunos, ajudando-os a reconhecer suas situações limite e a descobrir a viabilidade não testada por meio do diálogo coletivo. "Otro mundo es possible" é o refrão que primeiro me vem à mente quando penso no legado que Paulo nos deixou. A noção de assistencialismo de Freire para mim significa que devemos trabalhar coletivamente com as pessoas, em vez de trabalhar como indivíduos para as pessoas. Do contrário, corremos o risco de falar pelas pessoas - o que é uma forma de desumanizá-las.

Em certo sentido, podemos dizer que os educadores não ensinam as pessoas. Os educadores só podem criar condições e contextos para as pessoas aprendam. A habilidade de um professor é saber quais contextos funcionam melhor para grupos e indivíduos específicos. Como podemos criar o melhor meio ou ambientes que facilitem o aprendizado - este é o desafio. Digo aos meus alunos, não vou trabalhar para vocês, mas com vocês - vamos trabalhar juntos e co-criar nosso universo social para que o encontro pedagógico funcione horizontalmente, no interesse de todos nós, em um espírito de mutualidade. Não consigo decidir quais são os melhores contextos de aprendizagem para meus alunos - isso requer compreensão coletiva por meio do diálogo. Do contrário, como os alunos podem vir a perceber sua própria historicidade - como podem se esforçar para se tornar um sujeito da história em vez de um objeto da história?

Somos capazes de transgredir nosso embasamento ético justamente porque, como diz Freire na Pedagogia da Liberdade, "estamos em constante processo de nos tornar e, portanto, somos capazes de observar, comparar, avaliar, escolher, decidir, intervir, romper com, e fazer escolhas." Somos seres éticos capazes de se recusar a existir em uma "quietude fatalista" que Freire discute nos termos da "filosofia fatalista da política neoliberal" que "abandona os interesses humanos em favor do mercado". Vejo a questão da liberdade sendo abusada hoje por partidários de Trump em sua recusa em usar máscaras protetoras em meio à Pandemia.

Eles alegam que isso é uma violação de sua liberdade como cidadãos americanos. No entanto, a liberdade tem limites de acordo com Freire: "A liberdade ilimitada é uma negação da condição humana de inacabamento". Freire dá um bom conselho: "O grande desafio para o educador de mentalidade democrática é como transmitir um senso de limite que pode ser eticamente integrado pela própria liberdade." Esses anti-máscaras são livres para colocar a mim ou a meus familiares em risco pelo Covid-19? Aparentemente, eles pensam que são - 
eles pensam que é seu direito democrático. No entanto, ao mesmo tempo, todos eles usam cinto de segurança em seus carros e não pensariam em permitir que seus filhos viajassem no carro de um amigo sem colocar os cintos de segurança, mas sentem que é seu direito não usar máscara no supermercado ou área comercial. Todos nós que nos aventuramos no terreno da pedagogia crítica, que estivemos em piquetes ou aguentamos cassetetes e gás lacrimogêneo em protestos, estamos alinhados com Freire. Mas isso não significa que vejamos tão claramente quanto Freire via ou que tenhamos visão de longo prazo como ele.

Sempre haverá aqueles que afirmam ser os "verdadeiros" herdeiros do legado de Freire. É de se esperar neste mundo de "pernas para o ar", onde as pessoas anseiam por pertencer a linhagens sagradas e fazer parte do grupo "interno". Demorou décadas para que o trabalho de Paulo se tornasse um marco no pensamento educacional progressista e radical e os esforços para diluir suas ideias também estão em andamento. O que nos dá um Paulo Freire "de baixo custo e mais eficiente", que é amplamente distribuído em redes progressistas e que oferece a todos algo a preço de barganha. Muitas vezes, esses acólitos de Freire estão mais preocupados com o marketing de Freire do que com a compreensão da importância fundamental de seu trabalho. Freire queria criar um mundo onde a produção de valor (riqueza monetizada) pudesse ser abolida e onde a verdadeira igualdade social pudesse ser sustentada através da luta por uma democracia socialista. Seu objetivo foi movido por um amor pela humanidade.

Freire era um homem movido pelo amor - isso é claramente revelado por Nita Freire e outros. Também fica claro a partir de uma leitura sustentada da obra de Freire. Freire sempre criticou o fato de que existem classes sociais - alguns vivem na opulência enquanto outros sofrem. Ele se opôs à diferenciação da riqueza - que alguns deveriam ser ricos enquanto outros permanecem pobres. Durante a Grande Depressão de 1929, a família de Freire foi forçada à pobreza e Freire experimentou a humilhação sentida por seus pais em suas tentativas de alimentar um Paulo faminto. Esta foi a introdução de Freire na cultura do silêncio que forçou muitos brasileiros a nascer e morrer na pobreza. Ele forjou solidariedade com seus colegas de escola que também estavam famintos e viveram o suficiente para dar aos camponeses e às classes trabalhadoras um modelo ético, ontológico, epistemológico e pedagógico a partir do qual avançar em sua luta pela libertação, em sua luta por dignidade e um direito de viver - um molde para um modelo de parceria de educação que fornece um passo importante na direção de transformar um sistema de exploração de classe que mantém o privilégio de alguns às custas de muitos.

A co-intencionalidade que permeou a pedagogia de Freire levou a parcerias entre professores e alunos nas quais o professor e o aluno co-construiriam sua compreensão do mundo por meio de encontros dialógicos com a palavra e o mundo - e esses atos de conhecimento co-constitutivo tinham a pretensão de calcular a curva do arco do universo moral em que vivemos. $\mathrm{O}$ arco do universo moral não é voltado para a justiça. Precisamos dobrá-lo. Esse é todo o propósito da pedagogia crítica - ser capaz de adivinhar o arco de nosso universo moral por meio de nossa consciência e tentar dobrá-lo em direção à justiça. Freire nos dá uma concepção prática do que a justiça significa para milhões de pessoas oprimidas 
por ideologias, mitos, mentiras, arranjos sociopolíticos, relações sociais de produção capitalista, alegorias retóricas que se autoconfirmam.

Os governantes do mundo, os mestres da guerra e da opressão, não gostam da definição de justiça de Freire, uma vez que ela ameaça seu poder e privilégio. É por isso que Freire foi proibido em alguns países e seus livros proibidos. Seu trabalho foi proibido por alguns conselhos escolares aqui nos Estados Unidos. Para alguns revolucionários, Freire não foi militante o suficiente; para alguns progressistas liberais, ele foi militante demais. Ele não pode ser adequado para todos. A obra de Freire ganha urgência, dado o momento histórico em que vivemos e a especificidade contextual de nossa relação com o mundo nesse momento. Mas, apesar dos vários pontos de inflexão que encontramos ao longo do caminho trêmulo da história, o trabalho de Freire permanece continuamente relevante para a luta mais ampla pela decência e dignidade humanas. Por meio de sua participação implacável na luta pela justiça, a legitimidade da obra de Freire para o nosso tempo nunca vacila. A abertura de Freire à autocrítica é clara em sua resposta ao livro Mentoring the Mentor, no qual vários educadores norte-americanos (incluindo eu) participaram de uma avaliação das ideias de Freire. Aqui, ele se dirige ao professor que deseja usar as ideias de Freire como "certeza de aplicações técnicas à prova do professor". Adorei os comentários de Freire no posfácio: "Os educadores também romantizam minhas ideias sem uma maneira substantiva de entender o que significa ser freiriano.

Em suma, muitos desses educadores que superficialmente utilizam minha obra como forma de resolver pedagogicamente seus problemas técnicos são, em certo sentido, "turistas freirianos". Quase se tornam fundamentalistas freirianos, e assim o mundo se torna fixo, eliminando a possibilidade de a história ser uma possibilidade. O que proponho é exatamente o oposto. A história é sempre uma possibilidade não fixa ou predeterminada. Além disso, o educador progressista deve estar sempre se movendo por conta própria, continuamente me reinventando e reinventando o que significa ser democrático em seu próprio contexto cultural e histórico específico." O legado de Freire tem sido duradouro e continuará a ser, apesar das tentativas de alguns de reescrever, recodificar ou ressignificar suas palavras para que pareçam muito radicais ou muito conservadoras, muito ameaçadoras ou não suficientemente ameaçadoras, muito pós-modernas ou muito marxistas, muito preocupadas com práticas discursivas ou não preocupadas o suficiente em realizar a revolução final. Ou que suas citações de humanistas marxistas são muito ecléticas. O trabalho de Freire sobreviverá a essas críticas (que às vezes parecem mais agressões).

Assim como alguns professores esperam que Freire responda a todas as suas perguntas sobre como administrar suas salas de aula, os revolucionários também esperam que Freire desenvolva uma teoria abrangente para alcançar o socialismo. Freire não se propôs a atingir todos esses objetivos. No entanto, podemos apreciar Freire pelo que ele foi capaz de realizar. Em todas as obras de Freire, um coração singular está batendo, pulsando pelos corredores do poder político e econômico e pelos áridos sertões da pobreza - pois a obra de Freire tem tanto a ensinar aos opressores quanto aos produtores de cana de Pernambuco. Ele fala tanto para os poderosos de São Paulo e Nova York quanto para os habitantes da cidade-no-meio-donada, onde almoçou com um líder da Frente Farabundo Martí para la Liberación Nacional. 
Freire observou em Pedagogia da Esperança que as lideranças da FMLN "evitavam tanto as ilusões de um idealismo que atribui à educação um poder que ela não tem quanto o objetivismo mecanicista que nega qualquer valor à educação até que haja uma revolução”.

\section{Estamos vivenciando distopias e indignações face aos acintes à frágil democracia e aos recorrentes processos de perda de direitos sociais instaurados. Em sua perspectiva, qual o papel da obra de Paulo Freire na construção e consolidação de uma sociedade democrática?}

O legado de Paulo esmaga as narrativas inatacáveis do destino que o capitalismo neoliberal e seus intelectuais hegemônicos ocidentais reivindicam para suas vítimas cuidadosamente colocando as conquistas de Freire em uma teia sedentária de apreciação, como um troféu esportivo brilhante sentado no corredor do lado de fora de um ginásio de escola secundária, reduzindo as palavras de Freire para um tempo que já passou, sempre atrofiado, sempre peões das comunidades interpretativas que detêm a chave para abrir a caixa do troféu. Bolsonaro e seus covardes bajuladores pensam que possuem a chave do legado de Freire, mas estão gravemente enganados. É o povo que segura a chave, os trabalhadores do mundo, as classes populares sitiadas, aqueles que carregam a gema da opressão capitalista para que outros possam deleitar-se em suas fazendas, as massas sofredoras que anseiam que suas correntes sejam quebradas e por suas mentes e corpos, destruídos pela dor, sejam libertados. Apesar de sua ênfase no amor e na humildade, Freire não projetou uma abordagem pedagógica para libertar ninguém, mas sim uma abordagem de problematização por meio da qual as pessoas podem dar os passos necessários para se libertar - mas sempre em parceria com outras. Para todos os que se empenham seriamente em seu trabalho, ele os aproximará das condições coletivas de possibilidade necessárias para libertar suas mentes da escravidão ideológica, para se livrar das c da escravidão colonial, para agarrar as ferramentas necessárias para reconhecer e transcender as situações limites privando-os de seus direitos civis e econômicos - de sua dignidade e humanidade.

Freire nos convida a fazer parte de uma comunidade mais ampla na luta por um socialismo democrático, empregando uma epistemologia democrática radical que permite ao aluno pensar criticamente e agir moralmente resolvendo problemas por meio do raciocínio dialético, permitindo assim que o professor e o aluno aprendam um do outro - e esse é um dos aspectos mais poderosos de seu legado. Ele rejeitou o elitismo e a romantização da cultura dos oprimidos. Em vez disso, ele enfatizou um relacionamento semelhante ao relacionamento "eu-tu" descrito por Martin Buber.

Como Freire proclamou em sua famosa Pedagogia do Oprimido: "Não posso pensar autenticamente a menos que os outros pensem. Não posso pensar pelos outros, ou sem os outros." Ele ainda observa:

O eu e o tu tornam-se assim, na dialética dessas relações, dois tus que se tornam dois eus. A teoria dialógica da ação não envolve um sujeito, que domina em 
virtude da conquista, e um objeto dominado. Em vez disso, há sujeitos que se encontram para nomear o mundo a fim de transformá-lo.

Ele se sentia tão à vontade para se comunicar com os canavieiros pernambucanos quanto com os grandes intelectuais de sua época. Freire é, antes de tudo, um internacionalista, e seus conselhos são sempre dirigidos a um público global, como deixam claro suas palavras finais na Pedagogia da Indignação: 'Não importa em que sociedade estejamos, ou a que sociedade pertençamos, é urgente que lutemos com esperança e destemor.'

Freire foi tão crítico das abordagens vanguardistas de líderes revolucionários que evitam o diálogo em favor de revelar "a verdade" quanto foi dos professores autoritários que, por meio de seu "pedagogismo", simplesmente desejavam depositar seu conhecimento primitivo e intratável na mente dos alunos, como se seus cérebros não fossem mais do que caça-níqueis em um cassino em Las Vegas. A abordagem dialética de Freire para a cultura permitiu que seu trabalho fosse criticamente apropriado (reinventado) em vários contextos geopolíticos e em diferentes continentes. Seu sincero respeito pelos seres humanos proporcionou uma pedagogia multicultural que possibilitou a autodefinição coletiva e a recusa em ser "outro" ou tornado invisível pelas maquinações da cultura dominante e a persistente toxicidade do racismo. O trabalho de Freire foi capaz de formar uma ampla comunidade global entre a antipatia rebelde e as relações sociais alienadas que mancham esses tempos neoliberais.

O trabalho de Freire se tornou um guia importante em vários campos - educação, serviço social, sociologia do conhecimento, antropologia cultural, linguística, teologia, filosofia, composição em inglês, teoria literária, estudos de comunicação, ciência política, estudos para a paz e muito mais. Suas discussões de temas universais, como cidadania crítica, amor, a relação entre a subjetividade individual e o contexto social circundante mais amplo, autoridade e liberdade e opressão e libertação, ressoa entre todas as pessoas em vários ambientes sociais e atrai a atenção de educadores populares, organizações não governamentais e movimentos revolucionários. Por exemplo, fui recrutado para ajudar a trazer as ideias de Freire para a luta bolivariana na Venezuela. O presidente Hugo Chávez, não me surpreendeu saber, era um grande admirador de Freire.

Sua pedagogia está baseada em método dialético desenvolvido por meio de diálogo e em uma postura democrática, desconstruindo a tradicional relação entre professor que ensina e aluno que aprende.

Hoje, se ouvirmos com o coração, podemos ouvir Freire ecoado na música dos tropicalistas, nos ritmos do samba, nos tambores que ecoam dos terreiros e tendas, dos corais de templos esquecidos na celebração do equinócio da primavera; no Zócalo da Cidade do México, na melodia de Villa-Lobos, nas línguas faladas nas igrejas pentacostais da Zona Norte carioca, nas vozes de estudantes cantando uma canção de protesto de Chico Buarque de 1973 nas ruas de São Paulo, nas apresentações dos Dzi Croquetes na década de 1960 que derrubaram as portas da propriedade sexual ao desafiar as proibições do governo sobre o travestismo. E podemos sentir suas palavras desde os gritos dos manifestantes Black Lives Matter confrontando gás lacrimogêneo e policiais sanguinários nas ruas de Baltimore, até 
aqueles que buscam desestabilizar os binários políticos que compõem noções hegemônicas de nacionalismo e patriotismo.

E podemos sentir a sua camaradagem presente numa simples refeição de feijão e arroz entre amigos. Para mim, compreender o corpus de escritos poderoso e pioneiro de Paulo Freire envolve compreender desenvolvimentos teóricos rigorosos na crítica da ideologia que envolvem despir os enganos que nos impedem de perceber as verdades subjacentes por trás das formas debilitantes de doutrinação ideológica que preenchem nossas vidas cotidianas. Isso se manifestou aqui nos Estados Unidos durante as eleições presidenciais de 2020, nas quais a contínua mentira ao público de Trump e seus bajuladores republicanos de que a eleição foi roubada criou uma percepção pública entre os eleitores republicanos que acabou levando à tomada do edifício do Capitólio e uma série de mortes. O que Marx chamou de ideias dominantes da classe dominante precisa ser entendido no contexto das mídias sociais e da tecnologia digital e pós-digital e do desenvolvimento do estado de vigilância militarizado.

Compreender novas formas de formações ideológicas nesta Quarta Revolução Industrial exige mudanças sistêmicas no sistema capitalista se quisermos escapar dos aparatos de estado repressivos com cabeça de hidra que agora calibram nossa existência. As explicações dadas aos alunos sobre porque existe desigualdade de classes, muitas vezes se baseiam em uma concepção neo-weberiana de classe-como-grupo de status e não na luta de classes sobre as condições objetivas e materiais de existência e sugerem que a remediação dessa desigualdade de classes pode ser abordada de forma bem-sucedida com o próprio sistema capitalista. Os marxistas discordariam e argumentariam que a desigualdade está embutida na própria estrutura do capitalismo, razão pela qual precisamos de uma alternativa socialista ao capitalismo. Consequentemente, os educadores marxistas começaram a abordar as inadequações da pedagogia crítica em relação a sua evitação liberal de esquerda de qualquer discussão sobre a abolição da sociedade de classes. Hoje, precisamos claramente de uma pedagogia socialista e acredito que o trabalho de Paulo Freire é fundamental para desafiar as agendas políticas depravadas da classe plutocrática que foram normalizadas e armadas contra as populações mais vulneráveis que consistem em pobres e negros. As mentiras de que os professores foram disseminados pela classe capitalista transnacional foram forçosamente fabricadas pelos efeitos de criação de consenso da mídia tradicional. Os burgueses às vezes aparecem completamente vazios de conscientização, tanto que não conseguem ver seu próprio reflexo (exceto talvez num espelho de casa de diversões).

Como resultado dessa amnésia histórica, inação humana e sem uma preocupação fungível com a construção do socialismo, qualquer esperança que os progressistas tenham de reverter a devastação do capitalismo neoliberal e sua atração omnicida, ecocida e epistemicida pela acumulação militarizada ou acumulação por repressão é deixada para ser conjurado pelas próprias vítimas. $\mathrm{O}$ fracasso em quebrar o controle narrativo da mídia de massa que está em forte alinhamento com o ato político de classe pode levar a uma catástrofe ecológica antropogênica, ocasionando a extinção total da espécie humana por meio de armas semelhantes ao Armagedon. 


\section{Como a pedagogia crítica construída sobre a obra de Freire desafiará o sistema capitalista e exigirá a criação de um socialismo viável para nossos tempos?}

Acredito que este seja o desafio central para os educadores hoje. A epistemologia materialista dialética de Freire alimenta uma práxis revolucionária, uma preocupação com a ação, com a transformação, de protagonismo. Esta é a sua força, mas não há garantia de que perseverará por conta própria. Se isso vai prevalecer, depende de nós.

Para mim, o fundamento central da pedagogia de Freire é o da práxis revolucionária, o que chamo de práxis protagonista, que significa a capacidade de intervenção humana na realidade social objetiva que nos confronta, ou seja, o mundo material / corporal da necessidade e a luta pela libertação, das forças de austeridade que nos cercam. A obra de Freire não recua para o interior da subjetividade, mas enfatiza a ideia de protagonismo em direção à humanização - a ontologia humanística de Freire é clara. Ser e tornar-se agente da história. Isso ocupa lugar central tanto no humanismo de Freire quanto na filosofia humanista marxista. Mas pode a práxis de professores e alunos em ambientes de escola pública tornarse suficientemente protagonista em trazer mudanças sociais substantivas para a melhoria da humanidade? Seu foco para a mudança é muito estreito para mover o capitalismo de seu substrato, para abalar o capitalismo em suas raízes? De certa forma, a práxis freiriana pode ser comparada a refletir sobre o desempenho de suas ações e as situações limites que impedem sua intencionalidade, sua capacidade de engajar-se plenamente na história. A consciência para Freire refrata, em vez de refletir o mundo objetivo, levando a distorções ideológicas. Nossas lentes subjetivas estão ligadas à nossa imaginação e é difícil ver o mundo claramente se sua imaginação estiver fora de foco. Para Freire, a verdade do mundo pode ser conhecida em si mesma, mas apenas parcialmente. A práxis protagonista começa com a ação ética dentro e sobre o mundo, assim como com o mundo, não com a doutrina correta.

Aqui, a ação tem como premissa a crença na capacidade para a bondade humana e começa com agir eticamente. Marx nos lembra que os seres humanos revisam seu pensamento diante das várias mudanças em suas circunstâncias, e que os próprios educadores devem estar dispostos a ser educados. A prática revolucionária, ou práxis, tem a ver com "a coincidência da mudança das circunstâncias e da atividade humana ou da automudança" (Marx). Os agentes protagonistas ou revolucionários não nascem, são produzidos pelas circunstâncias. Para revolucionar o pensamento, é necessário revolucionar a sociedade - uma vez que o pensamento e as organizações sociais formam uma totalidade integrada. E, claro, revolucionar a sociedade significa revolucionar nosso pensamento. Todo desenvolvimento humano (incluindo pensamento e fala) é atividade social e tem suas raízes no trabalho coletivo. Essa ideia parece central para o trabalho de Freire e Marx. Os seres humanos podem se adaptar a novas circunstâncias e fazer mudanças. $\mathrm{O}$ conceito de práxis de Freire encontra eco aqui nas famosas linhas de Marx:

Os homens fazem sua própria história, mas não a fazem como querem; eles não o fazem sob circunstâncias selecionadas, mas sob circunstâncias já existentes, dadas e transmitidas do passado. A tradição de todas as gerações mortas pesa como um 
pesadelo no cérebro dos vivos. E assim como parecem ocupados em revolucionar a si mesmos e as coisas, criando algo que não existia antes, precisamente em tais épocas de crise revolucionária, eles ansiosamente invocam os espíritos do passado a seu serviço, pegando emprestado nomes, lemas de batalha, e trajes para apresentar esta nova cena na história mundial em disfarces consagrados e linguagem emprestada.

O trabalho de Freire sobre a intersubjetividade vem de Hegel, a quem Marx tinha uma grande dívida. A consciência crítica para Freire é criada na história e não como algum princípio abstrato fora dela e é o nosso meio de nos tornarmos totalmente, autenticamente e ontologicamente humanos, ao mesmo tempo em que nos esforçamos de forma criticamente utópica para criar um mundo de justiça, dignidade e possibilidade humana. A luta pela consciência crítica é essencialmente a luta pela capacidade de agir e assumir voz protagonista. A voz de uma pessoa não é simplesmente um órgão para se fazer ouvir, mas se torna uma práxis de intencionalidade, de protagonismo que permite uma inserção estratégica e crítica na história - na materialidade confusa da história. Quando se está inserido na história, isso não se dá isoladamente, mas por meio de uma relação dialógica com os outros. Assim como estamos no mundo e com o mundo simultaneamente, estamos em relação e com os alunos.

Freire entende que a consciência e o mundo "encarnam" dialeticamente e que a consciência que leva à conscientização significa penetrar profundamente no prêmio de consciência da realidade cotidiana por meio da problematização e do diálogo, a consciência se tornando cada vez mais crítica de si mesma - uma consciência da consciência, no ato de decodificar ou desvelar a realidade como um processo contínuo em um mundo não estático. Então, essencialmente, a pedagogia crítica de Freire é uma pedagogia da problematização que se recusa a dar respostas com antecedência. É uma abordagem existencial que se define pelas contingências que a confrontam. É uma pedagogia sem garantias e sem promessas, nascida de uma honestidade e integridade brutais, movida pela fé na humanidade e na bondade humana. Embora Freire tenha escrito sobre a Igreja, gostaria de tê-lo visto escrever sobre o papel da fé religiosa. A pedagogia de Freire não era otimista, mas era esperançosa no sentido de "cultura do silêncio" criada pela cultura dominante, não significa que os oprimidos não possam responder a suas próprias realidades. No "círculo de cultura", Freire demonstrou que a relação dialógica é possível, na qual educadores e educandos utilizaram codificações para dialogar sobre as condições sociais, culturais e materiais que impactam suas vidas no dia a dia. A abordagem de Freire para a alfabetização esbarrou na corrente dos métodos tradicionais de alfabetização que exigiam que os indivíduos aprendessem as palavras e ideias de livros ou materiais produzidos por aqueles que estão no poder.

O trabalho de Paulo Freire, proporcionou-nos olhares alargados para o sujeito, a sociedade e a educação tradicional, sobretudo quando formula radicais críticas à educação bancária e apresenta suas formulações sobre o tema gerador. Quais as 


\section{principais contribuições epistemológicas de Paulo Freire no processo de organização de currículo?}

Aprender a ler a partir de uma cartilha significa que os alunos devem aceitar as experiências inscritas na cartilha como mais importantes do que as suas próprias. Freire conseguiu identificar temas geradores que permeiam as vivências daqueles que acreditavam que as condições atuais de sua existência - como pobreza e analfabetismo - eram devidas ao destino, ou ao acaso, ou à própria inferioridade constitutiva, mas que tanto desejavam tornarse alfabetizados. Freire reconheceu que os alunos oprimidos haviam internalizado imagens profundamente negativas de si mesmos (imagens criadas e impostas pelo opressor) e se sentiam incapazes de ter uma participação ativa em seus próprios assuntos.

Os "temas geradores" que Freire foi capaz de apreender em suas atividades desenvolvidas com sujeitos em situação de opressão foram codificações de experiências complexas que tinham um grande significado social e significado político para o grupo e provavelmente gerariam considerável discussão e análise. Eles foram selecionados porque derivaram da especificidade contextual da história e das circunstâncias dos alunos. O 'método' de Freire (a obra de Freire não pode ser reduzida a um método estritamente falando, pois é mais uma filosofia política) consistia em uma fase investigativa de encontrar as palavras e os temas geradores de um grupo em termos de sua relevância de classe social e significado para esse grupo. A consciência crítica exigia a rejeição da passividade e a prática do diálogo. A consciência crítica foi produzida não através de um esforço individual ou intelectual, mas através da conscientização ou identificação de contradições na experiência vivida, e compreensão e superação de mitos, tradições e ideologias dominantes, a fim de alcançar novos níveis de consciência de ser um "objeto" em um mundo onde apenas "sujeitos" têm os meios para determinar a direção de suas vidas. O processo de conscientização envolveu se tornar um "sujeito" com outros sujeitos oprimidos e participar da humanização do mundo por meio da luta e da praxis coletivas. A conscientização envolveu vivenciar a realidade opressora como um processo que pode ser superado por meio da praxis transformadora. Eu vejo o ato de conhecer de Freire como baseado em um tipo de desejo mitopoético (um desejo de elevar nossa própria existência a um nível de maior significado) ligado à comunidade, a um novo nível de autenticidade sagrada, a organizar a vida de maneiras imaginativamente novas que recusam para reproduzir a alienação e objetivação necessariamente encontradas no mundo do trabalho abstrato.

O objetivo essencial de Freire é tornar-se consciente e transcender os limites em que podemos nos tornar. Conseguimos isso externalizando, historicizando e objetivando nossa visão de libertação, tratando a teoria como uma forma de prática e a prática como uma forma de teoria enquanto contestamos a psicopatologia da vida cotidiana encarnada na divisão social do trabalho do capitalismo. A práxis protagonista para Freire serve como base definitiva para o avanço e verificação de teorias, bem como para fornecer garantias para reivindicações de conhecimento. Em certo sentido, isso reflete o aprendizado ao fazer, segundo Dewey, mas o trabalho de Freire tem mais em comum com Marx do que Dewey, na minha opinião. 
Mas, em vez de descrever Freire como um homem com uma metodologia, preferiria descrevê-lo como um filósofo da práxis, um filósofo cuja obra nasce de suas próprias experiências concretas, sua história e biografia particulares encarnadas em uma conjuntura histórica específica. Se você captar a pedagogia de Freire com força suficiente, encontrará um homem retornando à sombra de uma mangueira depois de uma vida de luta corajosa e amorosa para permitir que outros se libertem da escravidão.

A dedicação de Freire à luta pela democracia muitas vezes exigia que professores e alunos trabalhassem juntos como co-participantes e parceiros na produção de conhecimento - para co-construir o currículo, para desempenhar um papel na construção de programas de educação. Mas Freire não via o papel dos professores principalmente como facilitador - ele acreditava que havia contextos pedagógicos nos quais os professores deveriam assumir um papel de liderança na sala de aula quando o professor mostrasse experiência suficiente e quando a situação exigisse. Freire escreve:

Existem muitas ocasiões em que um bom exemplo pedagógico orientado para a democracia é tomar a decisão em questão com os alunos, depois de analisar o problema. Outras vezes, quando a decisão a ser tomada está dentro do escopo da expertise do educador, não há razão para não agir, para ser negligente.

Uma das pré-condições para a construção de relações sociais democráticas é desenvolver voz e ação - ação protagonista. No entanto, isso é impossível quando o governo deseja controlar rigidamente todos os aspectos de como o ensino é administrado. Como escreve Freire:

Ninguém vive plenamente a democracia, nem a ajuda a crescer se, antes de tudo, é interrompido em seu direito de falar, de ter voz, de fazer seu discurso crítico, ou, em segundo lugar, se não estão engajados, de uma forma ou de outra, na luta pela defesa desse direito, que, afinal, também é o direito de agir.

Um dos principais problemas para bloquear o empoderamento dos professores no Brasil, como em outros lugares, é o tratamento dado aos professores pelo público. Como ele observou: "É imperativo que a profissão docente no Brasil seja tratada com dignidade para que a sociedade comece a exigir que a sociedade comece a desempenhar suas funções de forma eficaz. " Isso significa que os professores devem receber um aumento significativo no salário. Como escreve Freire:

Não podemos entrar no novo milênio com milhares de professores ditos leigos, mesmo nas áreas pobres do país, às vezes ganhando menos do que um saláriomínimo. São pessoas heroicas, generosas, amorosas, inteligentes, mas tratadas com desprezo pelas oligarquias nacionais.

O trabalho de Freire foi dedicado a ajudar professores e alunos a se empoderarem. Criar relações dialógicas entre professor e aluno é um dos principais meios de empoderar os alunos. 
Para Freire, "o diálogo centrado não apenas nos conteúdos a serem ensinados, mas na própria vida, se for verdadeiro, não só é válido do ponto de vista do ato de ensinar, mas também prepara um clima aberto e livre no ambiente de sua sala de aula."

Freire escreve que a práxis pela qual a consciência é mudada "não é apenas ação, mas ação e reflexão". Ele argumenta que a práxis teórica só é autêntica quando mantém o movimento dialético entre si e a especificidade contextual da práxis que se deseja realizar, isto é, quando é ciente da unidade entre prática e teoria na qual ambas são construídas, moldadas, e remodeladas. Em outras palavras, a práxis autêntica é um "movimento dialético que relaciona a reflexão crítica sobre a ação passada com a luta contínua".

Para Freire, uma pedagogia da libertação envolve uma "práxis social" que trata de "ajudar a libertar o ser humano da opressão que o estrangula em sua realidade objetiva". A práxis social, como explica Freire, é o que me atraiu para a tradição latino-americana da teologia da libertação, uma teologia que incentiva os oprimidos a criar e recriar-se na história de uma forma concreta, em vez de participar do que Freire chama de "uma repetição reformada do presente". Freire escreve: "Não posso me permitir ser um mero espectador. Pelo contrário, devo exigir meu lugar no processo de mudança. Portanto, a dramática tensão entre o passado e o futuro, a morte e a vida, o ser e o não ser, não é mais uma espécie de beco sem saída para mim; Posso ver o que realmente é: um desafio permanente ao qual devo responder. E minha resposta não pode ser outro senão minha práxis histórica - em outras palavras, práxis revolucionária." A pedagogia crítica inspirada em Freire oferece aos alunos várias linguagens de crítica e possibilidade através das quais eles podem compreender de uma forma mais matizada e granular a relação entre sua subjetividade individual e a sociedade em geral.

Dito de outra forma, os temas geradores na pedagogia freiriana potencialmente servem como redes elos dialéticos através dos quais os alunos podem, depois de Freire, 'ler o mundo' contra o ato de 'ler a palavra', isto é, examinar o mundo contra as experiências vividas por alguém, como essas experiências são refletidas ou refratadas por meio de várias teorias críticas, como várias teorias feministas, teorias que conectam gênero, raça e economia política, teorias que oferecem estruturas explicativas que podem ajudar os alunos a dar sentido às suas próprias experiências. O objetivo deste exercício filosófico diário é criar condições de consciência crítica ou auto-reflexividade crítica para que os sujeitos possam compreender melhor como as várias ideologias conduzem a vida social, para ajudar os sujeitos a discernir como os sistemas de inteligibilidade ou sistemas de mediação dentro da sociedade mais ampla (natureza, o sistema econômico, o estado, o sistema social, o sistema cultural, a jurisprudência, as escolas, a religião, etc.) são mutuamente constitutivos do self. O objetivo disso é a liberação, emancipação.

Quando Freire se refere à noção de auto-empoderamento social, ele está se referindo a uma relação dialética que impulsiona a produção de agência crítica. É imperativo não nos referirmos a nós mesmos e às relações sociais como se fossem categorias mutuamente exclusivas, antissepticamente distantes umas das outras. Eles não são termos fundidos de aço, mas sim fundem-se uns nos outros. Novamente, a produção de professores empoderados é dialética. É nesse ponto que chegamos à noção de práxis, a interação mutuamente constitutiva 
da teoria e da prática. A práxis começa com uma agência pessoal dentro e fora do mundo, guiada por um compromisso ético de servir as populações mais vulneráveis que sofrem desnecessariamente sob os regimes mais brutais do capital. Em outras palavras, começamos com a prática e então entramos em diálogo com outras pessoas significativas à medida que refletimos sobre nossa prática. Essa reflexão sobre nossa prática, então, informa a prática subsequente - e chamamos esse processo ou modo de aprendizagem experiencial de práxis revolucionária, ou comportamento auto-reflexivo com propósito, isto é, explorar com outros a relevância das ideias filosóficas para as falhas da vida cotidiana e a necessidade de transcendê-los. A pedagogia crítica de Freire é sobre a criação de uma cidadania crítica. O objetivo do diálogo é tornar o estranho familiar e o familiar estranho - é uma forma de questionar o que consideramos natural.

A intenção é construir um contexto pedagógico no qual o educador e os alunos abandonem as relações hierárquicas e o educador esteja disposto a ser educado pelos alunos e, quando isso funciona, cria um espaço liminar, um "momento subjuntivo" de "e se". E se o mundo fosse "assim" e não "assim"? E se fosse um lugar de alegria, amor, esperança e solidariedade, e não um lugar de precariedade, medo, ódio e divisão? O que a sociedade fez de mim? O que gosto no que a sociedade fez de mim e o que quero mudar? Como podemos nos ressocializar para que possamos construir um mundo onde, por exemplo, o capital não flua das classes trabalhadoras para os ricos? Como podemos nos refazer; como podemos criar espaços onde negociamos o que achamos significativo na vida? Todos os aspectos da vida têm uma dimensão pedagógica. Freire nos ensinou isso. Toda comunicação é pedagógica. Nossa aptidão e inspiração para nos tornarmos educadores de justiça social não deve ser esmagada, mesmo durante este tempo de ignorância que muda o mundo. A práxis freiriana traz mudanças nos padrões e comportamentos cotidianos, pensamentos e sentimentos, a fim de alcançar a emancipação da barbárie do capitalismo e das relações de dominação e opressão. A pedagogia crítica inspirada na práxis freiriana oferece meios para o desenvolvimento da autonomia coletiva e individual, da criticidade e da autorreflexividade crítica, para que professores e alunos não permaneçam passivos e incapazes de desafiar práticas autoritárias.

A pedagogia revolucionária de Paulo Freire ajuda a criar condições para capacidade dos alunos, para que se tornem sujeitos revolucionários. Isso não é fácil em um ambiente sob o espectro de políticas e práticas neoliberais. A bilionária secretária de educação de Trump, Betsy DeVos, foi o exemplo perfeito de uma administradora neoliberal que usava viseiras que limitavam imersões nos debates educacionais. Ela nem mesmo tinha curiosidades básicas sobre a história da educação pública. Na verdade, DeVos nutria uma hostilidade aberta à educação pública. Ela vem de uma tradição cuja ignorância obstinada sobre educação favorecia a eliminação de um Departamento Federal de Educação, preferindo, em vez disso, deixar que estados individuais tomassem as rédeas das decisões que afetavam as políticas e práticas escolares. DeVos era uma Ministra da Educação que nutria uma profunda desconfiança no governo, ecoando a afirmação de Ronald Reagan de que um governo expansivo era o problema não a solução. Os conservadores sempre atacaram o ensino moderno ou os livros didáticos progressistas e o papel desempenhado pela pedagogia crítica. 
DeVos estava particularmente preocupada com o socialismo. Ela argumentou que as escolas públicas e os "marxistas culturais" estavam subvertendo os valores da família ao falhar em reforçar as crenças religiosas dos cristãos conservadores. Isso não soa como Bolsonaro?

$\mathrm{O}$ apoio de DeVos aos valores cristãos conservadores e à privatização do sistema educacional não é nenhuma surpresa criado na tradição da Igreja Cristã Reformada - uma denominação calvinista holandesa conservadora pouco conhecida. Betsy DeVos gostaria de estender a definição de escolha de escola para que os contribuintes pagassem para qualquer aluno frequentar escolas charter, mesmo que sejam administradas por conselhos indicados frequentemente por empresas privadas. Hoje, como nunca antes, precisamos de Paulo Freire para trazer alguma sanidade a um mundo cruel que enlouqueceu.

Não é difícil ficar deprimido e afogado em cinismo, dado o estado da atual conjuntura histórica. Freire sempre nos lembrou de fazer um balanço das possibilidades de libertação envolvidas nas condições históricas atuais. Hoje é um desafio especial. A infecção revoltante do capitalismo e sua implacável cultura de aço de crueldade desenfreada que conhecemos como capitalismo de austeridade devastou o solo da humanidade, criando exércitos de vítimas fatigadas e desanimadas, oscilando entre desesperança, gestos fúteis de desafio e atos infundados de otimismo. Claramente, precisamos de uma abordagem de dupla vertente para a pedagogia crítica. Precisamos trabalhar em ambientes locais, comunitários, regionais e nacionais e consolidar nosso trabalho em todo o mundo com os movimentos sociais em todo o mundo. O Movimento Black Lives Matter teve sucesso recente não apenas nos Estados Unidos, mas em vários outros países. Precisamos construir um movimento transnacional em torno da pedagogia crítica enfatizando a ecopedagogia e a urgência em torno das mudanças climáticas e a necessidade de proteger nosso meio ambiente, de viver livremente sem a ameaça da violência racista, de conectar nosso movimento à luta pelo socialismo. Precisamos reestruturar nossas universidades em torno do modelo da comuna operária.

Novas iniciativas avançaram para recriar a imagem das universidades no modelo da cooperativa de trabalhadores, em vez de corporação e na crença do aluno como produtor. Os valores cooperativos que poderiam definir o novo design da universidade incluiriam, de acordo com Joss Winn: Autoajuda, Auto-responsabilidade, Democracia, Igualdade, Equidade e Solidariedade. Os princípios são filiação voluntária e aberta; Controle de membros democráticos; Participação econômica dos membros; Autonomia e Independência; Educação, Treinamento e Informação; Cooperação entre cooperativas; e Preocupação com a Comunidade. A plataforma para a construção de cooperativas de trabalhadores e para repensar a própria ideia de trabalho acadêmico na era do capitalismo cognitivo seria, neste modelo, o movimento cooperativo internacional (WINN, 2015). Da maneira como estão, as universidades são empregadores capitalistas que reproduzem o trabalho acadêmico na forma de trabalho estudantil. De acordo com Winn, o conhecimento produzido nesta forma de organização é alimentado pela produção de valor e existe principalmente como uma forma de mercadoria. Mas Joss Winn e Michael Neary e outros clamam pela transformação da universidade em uma universidade cooperativa administrada e de propriedade dos trabalhadores que controlaria os meios de produção de conhecimento e potencialmente produziria novas formas de conhecimento social através de uma forma de 'propriedade 
comum' de relações de propriedade que transformam a distinção entre 'público' e 'privado' a fim de criar um 'bem comum acadêmico' projetado para o bem da comunidade. Isso envolveria um novo tipo de relação aluno-professor por meio de formas de solidariedade, igualdade e mutualidade em termos de divisão do trabalho. Aqui, os modelos de negócios neoliberais baseados em precedentes institucionais são substituídos por modelos dialógicos freirianos baseados na análise materialista histórica que enfatiza o desenvolvimento da consciência crítica e da agência protagonista. As autoridades do Estado podem retirar as obras de Paulo das bibliotecas e das escolas, mas nunca podem matar suas ideias. Seu espírito corajoso vive.

Paulo Freire tem sofrido ataques pífios e desqualificadores de sua obra, por grupos neoconservadores (inclusive por quadros do alto escalão do Governo Bolsonaro), que o acusam de ser a principal referência para a doutrinação ideológica esquerdista. Essas manifestações de direita do Brasil têm raízes históricas, visando perenizar processos de exclusão. Mas, no atual cenário, como pensar os efeitos deste modus operandi do pensamento ultraconservador difuso na atmosfera social e as possibilidades de resistência?

Sim, devemos dar uma olhada nos perigos que vêm da direita política. Aqui nos Estados Unidos, Trump pratica ginástica com os fatos em que afirma ter sido o maior presidente dos Estados Unidos na história (exceto talvez no caso de Abraham Lincoln). Como pode Trump condenar outros quando encorajou a sedição contra seu próprio governo? Sim, aos olhos de milhões, ele cometeu traição contra os Estados Unidos, mas ainda tem milhões de seguidores que se atirariam do telhado de um arranha-céu se isso o agradasse. Nunca houve um único indivíduo tão perigosamente poderoso quanto Donald Trump e, embora ele não seja mais presidente, ele é o chefe de uma seita religiosa na qual é adorado como o salvador escolhido por Deus para a América. Sua maneira de lidar com a pandemia foi um ato de incompetência homicida, mas seus seguidores ainda acreditam que ele foi escolhido por Deus.

Em agosto de 2019, o New York Times publicou o Projeto 1619, que perturbou muito a administração Trump e os conservadores em todo o país. O Projeto 1619 visa reformular a "narrativa nacional" dos Estados Unidos. O projeto foi publicado pela primeira vez em agosto de 2019 para o $400^{\circ}$ aniversário da chegada dos primeiros africanos escravizados na colônia da Virgínia. O projeto posteriormente incluiu um artigo de jornal, eventos ao vivo e um podcast. O Projeto 1619 explora a história americana por meio de um enquadramento afroamericano que colocou no centro da fundação dos Estados Unidos os horrores do racismo e da escravidão. Aqui, o ideal americano de que "todos somos criados iguais" é fortemente desafiado pela realidade de que o país foi, de muitas maneiras, fundado nos legados brutais da violência racializada. Trump respondeu criando uma comissão por ordem executiva - a Comissão de 1776 - que foi criada para promover a "educação patriótica" e cruelmente atacar o chamado relato calunioso e antipatriótico da esquerda sobre a história dos Estados Unidos. 
Ele atacou a esquerda educacional como fornecedora do marxismo cultural. Este ataque à educação me lembra da atitude que Bolsonaro tem sobre a obra de Freire.

A ditadura militar no Brasil durou de 1964 a 1985. Quase 21 anos de governo autoritário. As políticas de nacionalismo e anticomunismo e as práticas de tortura e exílio de dissidentes são bem conhecidas. Assim como as invasões imperialistas do Vietnã e do Iraque pelos Estados Unidos e os horrores que os acompanharam. Trump, mas sua sombra espreita o país como um espectro do filme Nosferatu. Da mesma forma, posso ouvir Bolsonaro zurrando das bordas escuras de sua ópera distópica cotidiana, proclamando em sua voz estrondosa que ele é o líder mais "machista" e mais nacionalista do mundo. Ele fez seu pacto demoníaco com o capitalismo neoliberal (uma forma de capitalismo que já está em seus anos de crepúsculo) e permitiu que seu país queimasse - literalmente. O cérebro de Bolsonaro sempre foi um túmulo ideológico, onde a verdade vai morrer. A decência deu as costas a Bolsonaro muito antes de ele se tornar presidente. Ele é chamado de "Trump of the Tropics" e por boas razões. Seus cortes nos gastos sociais não são nenhuma surpresa, nem seu apelo para aumentar a idade mínima de aposentadoria. No que diz respeito à educação, Bolsonaro está usando o mesmo argumento de Trump - a educação está sendo assumida por marxistas culturais. E a educação pública é péssima e deve ser substituída por escolas particulares, religiosas e militares. Isso é errado na minha opinião. O dinheiro deveria ir para o aumento dos salários dos professores, para consertar o encanamento, a eletricidade, a infraestrutura das escolas públicas. A educação pública deve ser melhorada, não abandonada em favor de escolas particulares, religiosas ou militares. Na véspera de sua posse, Bolsonaro tuitou: "Um dos objetivos para tirar o Brasil das piores posições nos rankings internacionais de educação é combater o lixo marxista que se espalhou nas instituições de ensino." Enquanto fazia campanha, Bolsonaro disse que queria "entrar no Ministério da Educação com um lançachamas para remover Paulo Freire". Essas não são afirmações de um homem sério, mas representam as idéias de um bobo da corte ou do mestre de cerimônias de um circo. $\mathrm{O}$ Ministério da Educação desmantelou seu departamento de diversidade - o que diz muito.

Nos Estados Unidos e em outros lugares, é uma afirmação ridícula culpar marxistas culturais pelo estado da educação. Existem muito poucos acadêmicos marxistas nas universidades dos Estados Unidos e eu presumo que eles não tenham assumido as universidades ou faculdades de professores no Brasil. O marxismo cultural é uma "palavracódigo" criada pelos políticos de direita para difamar os acusados de ser politicamente correto, ou por apoiar os direitos de gays, lésbicas e transgêneros, por defender os direitos indígenas. É uma palavra usada para criticar os esforços anti-racistas em universidades, como a teoria crítica da raça ou a pedagogia crítica, e uma forma de se opor às críticas feministas. Trump se gabou de agarrar mulheres pela "buceta", atacou mexicanos como estupradores e assassinos, zombou de pessoas com deficiência, chamou algumas mulheres de feias em declarações públicas.

O marxismo cultural é uma teoria da conspiração anti-semita na qual membros da Escola de Teoria Crítica de Frankfurt (que eram judeus) e outros intelectuais judeus são acusados de fazer parte de uma conspiração bolchevique para destruir a cultura ocidental por serem "globalistas" em vez de "isolacionistas ", para apoiar o feminismo, o multiculturalismo, o 
politicamente correto e para criticar o privilégio branco e o patriarcado, ensinando aos alunos sobre a homossexualidade, apoiar a imigração como uma forma de diluir a identidade nacional, apoi a identidade transgênero, enfraquecendo os valores familiares e criando a categoria de crimes de ódio - isto é uma versão contemporânea do que os nazistas chamaram de Kulturbolschewismus ou Bolchevismo Cultural. O filho de Jair Bolsonaro afirmou que uniria forças com o guru de direita e ex-conselheiro de Trump, Steve Bannon, e derrotaria o marxismo cultural. Os neo-nazistas usam o conceito de "marxismo cultural" como uma cobertura para atacar liberais e progressistas. Em 2011, o terrorista norueguês Anders Behring Breivik massacrou 77 pessoas após postar um manifesto condenando a guerra cultural marxista. Claramente, a ideia do marxismo cultural é uma teoria da conspiração que não tem base em fatos. Em 2007, fui acusado de ensinar marxismo cultural na minha universidade (UCLA) e fui colocado em uma lista criada por políticos de direita - fui classificado como o "número um" em uma lista de 30 professores acusados de doutrinar estudantes para odiar os Estados Unidos. Éramos chamados de "trinta sujos". Os alunos receberam 100 dólares para gravar fitas de áudio secretas de minhas palestras e 50 dólares para fazer anotações sobre o que eu estava dizendo na sala de aula. Mas, na realidade, estou ensinando o que chamo de "cidadania crítica" - como tornar seu país melhor enfrentando seu passado - eventos bons e ruins.

Freire foi homenageado em 2012 como o patrono da educação no Brasil. Bolsonaro quer tirar Freire do título e dá-lo a São José de Anchieta, um missionário do século 16 nascido na Espanha, citando a "calamidade da educação nacional". Anchieta foi uma escolha estranha das forças políticas de direita, pois esse santo tinha muito em comum com Freire; foi virulento na denúncia da violência dos colonizadores portugueses e fundou uma escola para os indígenas. Já os reitores do Santuário de Anchieta, Nilson Marostica, S.J. e Bruno Franguelli, S.J., se opuseram a esta medida e elogiam publicamente a obra de Paulo Freire. Aparentemente, Vygotsky e Piaget também são culpados pela direita de, junto com Freire, contribuir para o marxismo cultural nas escolas brasileiras. Argumentos incrivelmente fracos contra Freire foram levantados pelo professor Paulo do Costa e outros defensores políticos. É claro que essa é uma tentativa de fazer de Freire um bode expiatório para as notas baixas de aproveitamento dos estudantes brasileiros em leitura, ciências e matemática. É projetado para atiçar convulsões públicas de medo e raiva, para chicotear e iluminar o público com desprezo em relação a Freire. Na Pedagogia do Coração, Freire escreve: "A busca pelo conhecimento nunca deve nos cansar, e a aquisição dele nunca deve nos deixar imóveis e satisfeitos." Freire estava sempre buscando, e para ele, um ser humano como todos nós, ele estava sempre crescendo, sempre pensando em novas idéias e se abrindo para o universo do amor, da compaixão e da compreensão, ao mesmo tempo em que nunca perdia a força, a convicção e o espírito guerreiro de luta. Bolsonaro e compaixão sempre tiveram uma grande disputa. Bolsonaro jamais se abriria às idéias de Paulo Freire. Talvez ele precise ser visitado pelos fantasmas do presente, passado e futuros natais de Dicken. Talvez ele precise participar de uma revisão de vida. Talvez Bolsonaro seja só fanfarronice e bravata. Mas não devemos nos preocupar com isso. O que precisamos agora é nos engajar nas pedagogias de Paulo da esperança, da liberdade, do coração, dos oprimidos e suas outras obras para que possamos 
alcançar a "libertação do medo" para continuar lutando contra as mentiras de Bolsonaro e seu irmão mais velho em-ódio, Donald Trump, e ser preenchido em espírito com as possibilidades emancipatórias que Freire nos ensinou a abraçar.

\section{Notas}

1. Tradução: Maria Vieira Silva - Universidade Federal de Uberlândia. Revisão de tradução: Amanda Magalhães Santiago - Doutoranda do Programa de Pós-Graduação em Estudos da Linguagem da Universidade Federal de Goiás (UFG). Tem mestrado em Estudos da Linguagem pela Universidade Federal de Goiás (UFG) - Regional Catalão, com estágio na University of Saskatchewan (Canadá) sob a supervisão do professor Shaun Murphy. É licenciada em Letras Português e Inglês pela Universidade Federal de Goiás (UFG) - Regional Catalão. É integrante do Grupo de Estudos e Pesquisas em Linguística Aplicada e Estudos da Linguagem (GEPLAEL) e atualmente faz parte do Grupo de Pesquisa Narrativa e Educação de Professores (GPNEP). E-mail: amanda.msantiago@gmail.com

2. Nota da tradutora: Em 1967 Paulo Freire publicou seu primeiro livro intitulado "educação como prática da liberdade" derivado de sua tese de concurso educação e atualidade brasileira, para a cadeira de história e educação - escola de belas artes de Pernambuco, Recife.

\section{Correspondência}

Maria Vieira Silva: Doutora em educação pela UNICAMP. Professora Titular da Faculdade de Educação da Universidade Federal de Uberlândia - UFU. Coordenadora do Grupo de Pesquisa Polis, Políticas, Educação e Cidadania.

E-mail: mvieiraufu@gmail.com

Texto publicado em Currículo sem Fronteiras com autorização dos autores. 